\title{
Class Frizzled GPCRs in GtoPdb v.2021.3
}

Elisa Arthofer ${ }^{1}$, Jacomijn Dijksterhuis ${ }^{2}$, Belma Hot $^{2}$, Paweł Kozielewicz ${ }^{2}$, Matthias Lauth ${ }^{3}$, Jessica Olofsson $^{2}$, Julian Petersen ${ }^{2}$, Tilman Polonio ${ }^{2}$, Gunnar Schulte ${ }^{2}$, Katerina Strakova ${ }^{2}$, Jana Valnohova ${ }^{2}$ and Shane Wright ${ }^{2}$

1. National Institute of Child Health and Human Development, USA

2. Karolinska Institutet, Sweden

3. Philipps-Universität Marburg, Germany

\begin{abstract}
Receptors of the Class Frizzled (FZD, nomenclature as agreed by the NC-IUPHAR

subcommittee on the Class Frizzled GPCRs [175]), are GPCRs originally identified in Drosophila [19], which are highly conserved across species. While SMO shows structural resemblance to the 10 FZDs, it is functionally separated as it mediates effects in the Hedgehog signaling pathway [175]. FZDs are activated by WNTs, which are cysteine-rich lipoglycoproteins with fundamental functions in ontogeny and tissue homeostasis. FZD signalling was initially divided into two pathways, being either dependent on the accumulation of the transcription regulator $\beta$-catenin or being $\beta$-cateninindependent (often referred to as canonical vs. non-canonical WNT/FZD signalling, respectively). WNT stimulation of FZDs can, in cooperation with the low density lipoprotein receptors LRP5 (O75197) and LRP6 (O75581), lead to the inhibition of a constitutively active destruction complex, which results in the accumulation of $\beta$-catenin and subsequently its translocation to the nucleus. $\beta$ catenin, in turn, modifies gene transcription by interacting with TCF/LEF transcription factors. WNT/ $\beta$-catenin-independent signalling can also be activated by FZD subtype-specific WNT surrogates [133]. $\beta$-catenin-independent FZD signalling is far more complex with regard to the diversity of the activated pathways. WNT/FZD signalling can lead to the activation of heterotrimeric G proteins [33, $178,150]$, the elevation of intracellular calcium [184], activation of cGMP-specific PDE6 [2] and elevation of cAMP as well as RAC-1, JNK, Rho and Rho kinase signalling [56]. Novel resonance energy transfer-based tools have allowed the study of the GPCR-like nature of FZDs in greater detail. Upon ligand stimulation, FZDs undergo conformational changes and signal via heterotrimeric $\mathrm{G}$ proteins [239, 240, 102, 174]. Furthermore, the phosphoprotein Dishevelled constitutes a key player in WNT/FZD signalling towards planar-cell-polarity-like pathways. Importantly, FZDs exist in at least two distinct conformational states that regulate pathway selection [240]. As with other GPCRs, members of the Frizzled family are functionally dependent on the arrestin scaffolding protein for internalization [22], as well as for $\beta$-catenin-dependent [13] and -independent [89, 14] signalling. The pattern of cell signalling is complicated by the presence of additional ligands, which can enhance or inhibit FZD signalling (secreted Frizzled-related proteins (sFRP), Wnt-inhibitory factor (WIF), sclerostin or Dickkopf (DKK)), as well as modulatory (co)-receptors with Ryk, ROR1, ROR2 and Kremen, which may also function as independent signalling proteins.
\end{abstract}

\section{Contents}

This is a citation summary for Class Frizzled GPCRs in the Guide to Pharmacology database (GtoPdb). It exists purely as an adjunct to the database to facilitate the recognition of citations to and from the database by citation analyzers. Readers will almost certainly want to visit the relevant sections of the database which are given here under database links.

GtoPdb is an expert-driven guide to pharmacological targets and the substances that act on them. GtoPdb is a reference work which is most usefully represented as an on-line database. As in any publication this work should be appropriately cited, and the papers it cites should also be recognized. This document provides a citation for the relevant parts of the database, and also provides a reference list for the research cited by those parts. For further details see [15].

Please note that the database version for the citations given in GtoPdb are to the most recent preceding version in which the family or its subfamilies and targets were substantially changed. The 
links below are to the current version. If you need to consult the cited version, rather than the most recent version, please contact the GtoPdb curators.

\section{Database links}

Class Frizzled GPCRs

https://www.guidetopharmacology.org/GRAC/FamilyDisplayForward?familyId=25

Introduction to Class Frizzled GPCRs

https://www.guidetopharmacology.org/GRAC/FamilyIntroductionForward?familyId=25

Receptors

$\mathrm{FZD}_{1}$

https://www.guidetopharmacology.org/GRAC/ObjectDisplayForward?objectId=229

$\mathrm{FZD}_{2}$

https://www.guidetopharmacology.org/GRAC/ObjectDisplayForward?objectId=230

$\mathrm{FZD}_{3}$

https://www.guidetopharmacology.org/GRAC/ObjectDisplayForward?objectId=231

$\mathrm{FZD}_{4}$

https://www.guidetopharmacology.org/GRAC/ObjectDisplayForward?objectId=232

$\mathrm{FZD}_{5}$

https://www.guidetopharmacology.org/GRAC/ObjectDisplayForward?objectId=233

$\mathrm{FZD}_{6}$

https://www.guidetopharmacology.org/GRAC/ObjectDisplayForward?objectId=234

$\mathrm{FZD}_{7}$

https://www.guidetopharmacology.org/GRAC/ObjectDisplayForward?objectId=235

$\mathrm{FZD}_{8}$

https://www.guidetopharmacology.org/GRAC/ObjectDisplayForward?objectId=236

$\mathrm{FZD}_{9}$

https://www.guidetopharmacology.org/GRAC/ObjectDisplayForward?objectId=237

$\mathrm{FZD}_{10}$

https://www.guidetopharmacology.org/GRAC/ObjectDisplayForward?objectId=238

$\mathrm{SMO}$

https://www.guidetopharmacology.org/GRAC/ObjectDisplayForward?objectId=239

\section{References}

1. Acevedo VD, Gangula RD, Freeman KW, Li R, Zhang Y, Wang F, Ayala GE, Peterson LE, Ittmann M and Spencer DM. (2007) Inducible FGFR-1 activation leads to irreversible prostate adenocarcinoma and an epithelial-to-mesenchymal transition. Cancer Cell 12: 559-71 [PMID:18068632]

2. Ahumada A, Slusarski DC, Liu X, Moon RT, Malbon CC and Wang HY. (2002) Signaling of rat Frizzled-2 through phosphodiesterase and cyclic GMP. Science 298: 2006-10 [PMID:12471263]

3. Albers J, Schulze J, Beil FT, Gebauer M, Baranowsky A, Keller J, Marshall RP, Wintges K, Friedrich FW and Priemel M et al.. (2011) Control of bone formation by the serpentine receptor Frizzled-9. J Cell Biol 192: 1057-72 [PMID:21402791]

4. Angers S and Moon RT. (2009) Proximal events in Wnt signal transduction. Nat Rev Mol Cell Biol 10: 468-77 [PMID:19536106]

5. Arthofer E, Hot B, Petersen J, Strakova K, Jäger S, Grundmann M, Kostenis E, Gutkind JS and Schulte G. (2016) WNT Stimulation Dissociates a Frizzled 4 Inactive-State Complex with Ga12/13. Mol Pharmacol 90: 447-59 [PMID:27458145]

6. AstraZeneca. AZD8542.

7. Bao X, Peng Y, Lu X, Yang J, Zhao W, Tan W and Dong X. (2016) Synthesis and evaluation of novel benzylphthalazine derivatives as hedgehog signaling pathway inhibitors. Bioorg Med Chem Lett 26: 3048-3051 [PMID:27180012]

8. Bengochea A, de Souza MM, Lefrançois L, Le Roux E, Galy O, Chemin I, Kim M, Wands JR, Trepo C and Hainaut P et al.. (2008) Common dysregulation of Wnt/Frizzled receptor elements in human hepatocellular carcinoma. Br J Cancer 99: 143-50 [PMID:18577996]

9. Bethge N, Honne H, Hilden V, Trøen G, Eknæs M, Liestøl K, Holte H, Delabie J, Smeland EB and Lind GE. (2013) Identification of highly methylated genes across various types of B-cell nonhodgkin lymphoma. PLoS ONE 8: e79602 [PMID:24260260]

10. Borello U, Berarducci B, Murphy P, Bajard L, Buffa V, Piccolo S, Buckingham M and Cossu G. (2006) The Wnt/beta-catenin pathway regulates Gli-mediated Myf5 expression during somitogenesis. Development 133: 3723-32 [PMID:16936075]

11. Borello U, Buffa V, Sonnino C, Melchionna R, Vivarelli E and Cossu G. (1999) Differential expression of the Wnt putative receptors Frizzled during mouse somitogenesis. Mech Dev 89: 
173-7 [PMID:10559494]

12. Bravo DT, Yang YL, Kuchenbecker K, Hung MS, Xu Z, Jablons DM and You L. (2013) Frizzled-8 receptor is activated by the Wnt-2 ligand in non-small cell lung cancer. BMC Cancer 13: 316 [PMID:23815780]

13. Bryja V, Gradl D, Schambony A, Arenas E and Schulte G. (2007) Beta-arrestin is a necessary component of Wnt/beta-catenin signaling in vitro and in vivo. Proc Natl Acad Sci USA 104: 6690-5 [PMID:17426148]

14. Bryja V, Schambony A, Cajánek L, Dominguez I, Arenas E and Schulte G. (2008) Beta-arrestin and casein kinase 1/2 define distinct branches of non-canonical WNT signalling pathways. EMBO Rep 9: 1244-50 [PMID:18953287]

15. Buneman P, Christie G, Davies JA, Dimitrellou R, Harding SD, Pawson AJ, Sharman JL and Wu Y. (2020) Why data citation isn't working, and what to do about it Database 2020 [PMID:32367113]

16. Byrne EFX, Sircar R, Miller PS, Hedger G, Luchetti G, Nachtergaele S, Tully MD, MydockMcGrane L, Covey DF and Rambo RP et al.. (2016) Structural basis of Smoothened regulation by its extracellular domains. Nature 535: 517-522 [PMID:27437577]

17. Canny CL and Oliver GL. (1976) Fluorescein angiographic findings in familial exudative vitreoretinopathy. Arch Ophthalmol 94: 1114-20 [PMID:947162]

18. Carmon KS and Loose DS. (2008) Secreted frizzled-related protein 4 regulates two Wnt7a signaling pathways and inhibits proliferation in endometrial cancer cells. Mol Cancer Res 6: 1017-28 [PMID:18567805]

19. Chan SD, Karpf DB, Fowlkes ME, Hooks M, Bradley MS, Vuong V, Bambino T, Liu MY, Arnaud CD and Strewler GJ et al.. (1992) Two homologs of the Drosophila polarity gene frizzled (fz) are widely expressed in mammalian tissues. J Biol Chem 267: 25202-7 [PMID:1334084]

20. Chen JK, Taipale J, Young KE, Maiti T and Beachy PA. (2002) Small molecule modulation of Smoothened activity. Proc Natl Acad Sci USA 99: 14071-6 [PMID:12391318]

21. Chen M, Wang J, Lu J, Bond MC, Ren XR, Lyerly HK, Barak LS and Chen W. (2009) The antihelminthic niclosamide inhibits Wnt/Frizzled1 signaling. Biochemistry 48: 10267-74 [PMID:19772353]

22. Chen W, Kirkbride KC, How T, Nelson CD, Mo J, Frederick JP, Wang XF, Lefkowitz RJ and Blobe GC. (2003) Beta-arrestin 2 mediates endocytosis of type III TGF-beta receptor and downregulation of its signaling. Science 301: 1394-7 [PMID:12958365]

23. Chen W, ten Berge D, Brown J, Ahn S, Hu LA, Miller WE, Caron MG, Barak LS, Nusse R and Lefkowitz RJ. (2003) Dishevelled 2 recruits beta-arrestin 2 to mediate Wnt5A-stimulated endocytosis of Frizzled 4. Science 301: 1391-1394 [PMID:12958364]

24. Chien AJ, Conrad WH and Moon RT. (2009) A Wnt survival guide: from flies to human disease. $J$ Invest Dermatol 129: 1614-27 [PMID:19177135]

25. Clevers H and Nusse R. (2012) Wnt/B-catenin signaling and disease. Cell 149: 1192-205 [PMID:22682243]

26. Corcoran RB and Scott MP. (2006) Oxysterols stimulate Sonic hedgehog signal transduction and proliferation of medulloblastoma cells. Proc Natl Acad Sci USA 103: 8408-13 [PMID:16707575]

27. Criswick VG and Schepens CL. (1969) Familial exudative vitreoretinopathy. Am J Ophthalmol 68: 578-94 [PMID:5394449]

28. Dann CE, Hsieh JC, Rattner A, Sharma D, Nathans J and Leahy DJ. (2001) Insights into Wnt binding and signalling from the structures of two Frizzled cysteine-rich domains. Nature $\mathbf{4 1 2}$ 86-90 [PMID:11452312]

29. Daudet N, Ripoll C, Molès JP and Rebillard G. (2002) Expression of members of Wnt and Frizzled gene families in the postnatal rat cochlea. Brain Res Mol Brain Res 105: 98-107 [PMID:12399112]

30. DeAlmeida VI, Miao L, Ernst JA, Koeppen H, Polakis P and Rubinfeld B. (2007) The soluble wnt receptor Frizzled8CRD-hFc inhibits the growth of teratocarcinomas in vivo. Cancer Res 67: 5371-9 [PMID:17545618]

31. Deshpande I, Liang J, Hedeen D, Roberts KJ, Zhang Y, Ha B, Latorraca NR, Faust B, Dror RO and Beachy PA et al.. (2019) Smoothened stimulation by membrane sterols drives Hedgehog pathway activity. Nature 571: 284-288 [PMID:31263273]

32. Dickins EM and Salinas PC. (2013) Wnts in action: from synapse formation to synaptic maintenance. Front Cell Neurosci 7: 162 [PMID:24223536]

33. Dijksterhuis JP, Petersen J and Schulte G. (2013) WNT/Frizzled signaling: receptor-ligand selectivity with focus on FZD-G protein signaling and its physiological relevance. BrJ Pharmacol [PMID:24032637]

34. Dufourcq P, Leroux L, Ezan J, Descamps B, Lamazière JM, Costet P, Basoni C, Moreau C, Deutsch U and Couffinhal T et al.. (2008) Regulation of endothelial cell cytoskeletal reorganization by a secreted frizzled-related protein-1 and frizzled 4- and frizzled 7-dependent pathway: role in neovessel formation. Am J Pathol 172: 37-49 [PMID:18156211]

35. Endo Y, Beauchamp E, Woods D, Taylor WG, Toretsky JA, Uren A and Rubin JS. (2008) Wnt-3a 
and Dickkopf-1 stimulate neurite outgrowth in Ewing tumor cells via a Frizzled3- and c-Jun Nterminal kinase-dependent mechanism. Mol Cell Biol 28: 2368-79 [PMID:18212053]

36. Favre CJ, Mancuso M, Maas K, McLean JW, Baluk P and McDonald DM. (2003) Expression of genes involved in vascular development and angiogenesis in endothelial cells of adult lung. $A m \mathrm{~J}$ Physiol Heart Circ Physiol 285: H1917-38 [PMID:12842817]

37. Fischer T, Guimera J, Wurst W and Prakash N. (2007) Distinct but redundant expression of the Frizzled Wnt receptor genes at signaling centers of the developing mouse brain. Neuroscience 147: 693-711 [PMID:17582687]

38. Foord SM, Bonner TI, Neubig RR, Rosser EM, Pin JP, Davenport AP, Spedding M and Harmar AJ. (2005) International Union of Pharmacology. XLVI. G protein-coupled receptor list. Pharmacol Rev 57: 279-88 [PMID:15914470]

39. Fröjmark AS, Schuster J, Sobol M, Entesarian M, Kilander MB, Gabrikova D, Nawaz S, Baig SM, Schulte G and Klar J et al.. (2011) Mutations in frizzled 6 cause isolated autosomal-recessive nail dysplasia. Am J Hum Genet 88: 852-60 [PMID:21665003]

40. Fujimoto T, Tomizawa M and Yokosuka O. (2009) SiRNA of frizzled-9 suppresses proliferation and motility of hepatoma cells. Int J Oncol 35: 861-6 [PMID:19724923]

41. Fukukawa C, Hanaoka H, Nagayama S, Tsunoda T, Toguchida J, Endo K, Nakamura Y and Katagiri T. (2008) Radioimmunotherapy of human synovial sarcoma using a monoclonal antibody against FZD10. Cancer Sci 99: 432-40 [PMID:18271942]

42. Fukukawa C, Nagayama S, Tsunoda T, Toguchida J, Nakamura Y and Katagiri T. (2009) Activation of the non-canonical Dvl-Rac1-JNK pathway by Frizzled homologue 10 in human synovial sarcoma. Oncogene 28: 1110-20 [PMID:19137009]

43. Gao Y and Wang HY. (2006) Casein kinase 2 Is activated and essential for Wnt/beta-catenin signaling. J Biol Chem 281: 18394-400 [PMID:16672224]

44. Gao Y and Wang HY. (2007) Inositol pentakisphosphate mediates Wnt/beta-catenin signaling. $J$ Biol Chem 282: 26490-502 [PMID:17595165]

45. Gazit A, Yaniv A, Bafico A, Pramila T, Igarashi M, Kitajewski J and Aaronson SA. (1999) Human frizzled 1 interacts with transforming Wnts to transduce a TCF dependent transcriptional response. Oncogene 18: 5959-66 [PMID:10557084]

46. Generoso SF, Giustiniano M, La Regina G, Bottone S, Passacantilli S, Di Maro S, Cassese H, Bruno A, Mallardo M and Dentice M et al.. (2015) Pharmacological folding chaperones act as allosteric ligands of Frizzled4. Nat Chem Biol 11: 280-6 [PMID:25751279]

47. Gitter KA, Rothschild H, Waltman DD, Scott B and Azar P. (1978) Dominantly inherited peripheral retinal neovascularization. Arch Ophthalmol 96: 1601-5 [PMID:687201]

48. Golan T, Yaniv A, Bafico A, Liu G and Gazit A. (2004) The human Frizzled 6 (HFz6) acts as a negative regulator of the canonical Wnt. beta-catenin signaling cascade. J Biol Chem 279: 14879-88 [PMID:14747478]

49. Gordon MD and Nusse R. (2006) Wnt signaling: multiple pathways, multiple receptors, and multiple transcription factors. J Biol Chem 281: 22429-22433 [PMID:16793760]

50. Gorojankina T, Hoch L, Faure H, Roudaut H, Traiffort E, Schoenfelder A, Girard N, Mann A, Manetti F and Solinas A et al.. (2013) Discovery, molecular and pharmacological characterization of GSA-10, a novel small-molecule positive modulator of Smoothened. Mol Pharmacol 83: 1020-9 [PMID:23448715]

51. Gow J and Oliver GL. (1971) Familial exudative vitreoretinopathy. An expanded view. Arch Ophthalmol 86: 150-5 [PMID:5571414]

52. Gregorieff A, Pinto D, Begthel H, Destrée O, Kielman M and Clevers H. (2005) Expression pattern of Wnt signaling components in the adult intestine. Gastroenterology 129: 626-38 [PMID:16083717]

53. Gregory MA, Phang TL, Neviani P, Alvarez-Calderon F, Eide CA, O'Hare T, Zaberezhnyy V, Williams RT, Druker BJ and Perrotti D et al.. (2010) Wnt/Ca2+/NFAT signaling maintains survival of $\mathrm{Ph}+$ leukemia cells upon inhibition of Bcr-Abl. Cancer Cell 18: 74-87 [PMID:20609354]

54. Guo N, Hawkins C and Nathans J. (2004) Frizzled6 controls hair patterning in mice. Proc Natl Acad Sci USA 101: 9277-81 [PMID:15169958]

55. Gurney A, Axelrod F, Bond CJ, Cain J, Chartier C, Donigan L, Fischer M, Chaudhari A, Ji M and Kapoun AM et al.. (2012) Wnt pathway inhibition via the targeting of Frizzled receptors results in decreased growth and tumorigenicity of human tumors. Proc Natl Acad Sci USA 109: 1171722 [PMID:22753465]

56. Hansen C, Howlin J, Tengholm A, Dyachok O, Vogel WF, Nairn AC, Greengard P and Andersson T. (2009) Wnt-5a-induced phosphorylation of DARPP-32 inhibits breast cancer cell migration in a CREB-dependent manner. J Biol Chem 284: 27533-43 [PMID:19651774]

57. Heinonen KM, Vanegas JR, Lew D, Krosl J and Perreault C. (2011) Wnt4 enhances murine hematopoietic progenitor cell expansion through a planar cell polarity-like pathway. PLoS ONE 6: e19279 [PMID:21541287]

58. Hendrickx M and Leyns L. (2008) Non-conventional Frizzled ligands and Wnt receptors. Dev 
Growth Differ 50: 229-43 [PMID:18366384]

59. Hoch L, Faure H, Roudaut H, Schoenfelder A, Mann A, Girard N, Bihannic L, Ayrault O, Petricci E and Taddei M et al.. (2015) MRT-92 inhibits Hedgehog signaling by blocking overlapping binding sites in the transmembrane domain of the Smoothened receptor. FASEB J 29: 1817-29 [PMID:25636740]

60. Holcombe RF, Marsh JL, Waterman ML, Lin F, Milovanovic T and Truong T. (2002) Expression of Wnt ligands and Frizzled receptors in colonic mucosa and in colon carcinoma. MP, Mol Pathol 55: 220-6 [PMID:12147710]

61. Hot B, Valnohova J, Arthofer E, Simon K, Shin J, Uhlén M, Kostenis E, Mulder J and Schulte G. (2017) FZD10-Ga13 signalling axis points to a role of FZD10 in CNS angiogenesis. Cell Signal 32: 93-103 [PMID:28126591]

62. Hsieh JC, Rattner A, Smallwood PM and Nathans J. (1999) Biochemical characterization of Wntfrizzled interactions using a soluble, biologically active vertebrate Wnt protein. Proc Natl Acad Sci USA 96: 3546-51 [PMID:10097073]

63. Hsieh M, Boerboom D, Shimada M, Lo Y, Parlow AF, Luhmann UF, Berger W and Richards JS. (2005) Mice null for Frizzled4 (Fzd4-/-) are infertile and exhibit impaired corpora lutea formation and function. Biol Reprod 73: 1135-46 [PMID:16093361]

64. Huang P, Zheng S, Wierbowski BM, Kim Y, Nedelcu D, Aravena L, Liu J, Kruse AC and Salic A. (2018) Structural Basis of Smoothened Activation in Hedgehog Signaling. Cell 174: 312-324.e16 [PMID:29804838]

65. Hughes KR, Sablitzky F and Mahida YR. (2011) Expression profiling of Wnt family of genes in normal and inflammatory bowel disease primary human intestinal myofibroblasts and normal human colonic crypt epithelial cells. Inflamm Bowel Dis 17: 213-20 [PMID:20848536]

66. Ide M, Muratake T, Yamada K, Iwayama-Shigeno Y, Iwamoto K, Takao H, Toyota T, Kaneko N, Minabe Y and Nakamura K et al.. (2004) Genetic and expression analyses of FZD3 in schizophrenia. Biol Psychiatry 56: 462-5 [PMID:15364045]

67. Inestrosa NC and Arenas E. (2010) Emerging roles of Wnts in the adult nervous system. Nat Rev Neurosci 11: 77-86 [PMID:20010950]

68. Ishikawa T, Tamai Y, Zorn AM, Yoshida H, Seldin MF, Nishikawa S and Taketo MM. (2001) Mouse Wnt receptor gene Fzd5 is essential for yolk sac and placental angiogenesis. Development 128: 25-33 [PMID:11092808]

69. Janda CY, Waghray D, Levin AM, Thomas C and Garcia KC. (2012) Structural basis of Wnt recognition by Frizzled. Science 337: 59-64 [PMID:22653731]

70. Janssens N, Andries L, Janicot M, Perera T and Bakker A. (2004) Alteration of frizzled expression in renal cell carcinoma. Tumour Biol 25: 161-71 [PMID:15557753]

71. Jenei V, Sherwood V, Howlin J, Linnskog R, Säfholm A, Axelsson L and Andersson T. (2009) A tbutyloxycarbonyl-modified Wnt5a-derived hexapeptide functions as a potent antagonist of Wnt5a-dependent melanoma cell invasion. Proc Natl Acad Sci USA 106: 19473-8 [PMID:19901340]

72. Jiang Y, Dunbar A, Gondek LP, Mohan S, Rataul M, O'Keefe C, Sekeres M, Saunthararajah Y and Maciejewski JP. (2009) Aberrant DNA methylation is a dominant mechanism in MDS progression to AML. Blood 113: 1315-25 [PMID:18832655]

73. Kang G, Yue W, Zhang J, Huebner M, Zhang H, Ruan Y, Lu T, Ling Y, Zuo Y and Zhang D. (2008) Two-stage designs to identify the effects of SNP combinations on complex diseases. J Hum Genet 53: 739-46 [PMID:18584117]

74. Karasawa T, Yokokura H, Kitajewski J and Lombroso PJ. (2002) Frizzled-9 is activated by Wnt-2 and functions in Wnt/beta -catenin signaling. J Biol Chem 277: 37479-86 [PMID:12138115]

75. Kasai K, Takahashi M, Osumi N, Sinnarajah S, Takeo T, Ikeda H, Kehrl JH, Itoh G and Arnheiter H. (2004) The G12 family of heterotrimeric G proteins and Rho GTPase mediate Sonic hedgehog signalling. Genes Cells 9: 49-58 [PMID:14723707]

76. Katanaev VL and Buestorf S. Frizzled Proteins are bona fide G Protein-Coupled Receptors.

77. Katsu T, Ujike H, Nakano T, Tanaka Y, Nomura A, Nakata K, Takaki M, Sakai A, Uchida N and Imamura T et al.. (2003) The human frizzled-3 (FZD3) gene on chromosome 8p21, a receptor gene for Wnt ligands, is associated with the susceptibility to schizophrenia. Neurosci Lett 353: 53-6 [PMID:14642436]

78. Kaucká M, Plevová K, Pavlová S, Janovská P, Mishra A, Verner J, Procházková J, Krejcí P, Kotasková J and Ovesná P et al.. (2013) The planar cell polarity pathway drives pathogenesis of chronic lymphocytic leukemia by the regulation of B-lymphocyte migration. Cancer Res 73: 1491-501 [PMID:23338609]

79. Kawasaki A, Torii K, Yamashita Y, Nishizawa K, Kanekura K, Katada M, Ito M, Nishimoto I, Terashita K and Aiso S et al.. (2007) Wnt5a promotes adhesion of human dermal fibroblasts by triggering a phosphatidylinositol-3 kinase/Akt signal. Cell Signal 19: 2498-506 [PMID:17804197]

80. Kaykas A, Yang-Snyder J, Héroux M, Shah KV, Bouvier M and Moon RT. (2004) Mutant Frizzled 4 associated with vitreoretinopathy traps wild-type Frizzled in the endoplasmic reticulum by oligomerization. Nat Cell Biol 6: 52-58 [PMID:14688793] 
81. Keay SK, Szekely Z, Conrads TP, Veenstra TD, Barchi Jr JJ, Zhang CO, Koch KR and Michejda CJ. (2004) An antiproliferative factor from interstitial cystitis patients is a frizzled 8 protein-related sialoglycopeptide. Proc Natl Acad Sci USA 101: 11803-8 [PMID:15282374]

82. Kemp CR, Willems E, Wawrzak D, Hendrickx M, Agbor Agbor T and Leyns L. (2007) Expression of Frizzled5, Frizzled7, and Frizzled10 during early mouse development and interactions with canonical Wnt signaling. Dev Dyn 236: 2011-9 [PMID:17576136]

83. Khan NI, Bradstock KF and Bendall LJ. (2007) Activation of Wnt/beta-catenin pathway mediates growth and survival in B-cell progenitor acute lymphoblastic leukaemia. Br J Haematol 138: 338-48 [PMID:17614820]

84. Kikuchi A, Yamamoto H and Kishida S. (2007) Multiplicity of the interactions of Wnt proteins and their receptors. Cell Signal 19: 659-71 [PMID:17188462]

85. Kikuchi A, Yamamoto H and Sato A. (2009) Selective activation mechanisms of Wnt signaling pathways. Trends Cell Biol 19: 119-29 [PMID:19208479]

86. Kilander MB, Dahlström J and Schulte G. (2014) Assessment of Frizzled 6 membrane mobility by FRAP supports G protein coupling and reveals WNT-Frizzled selectivity. Cell Signal 26: 1943-9 [PMID:24873871]

87. Kilander MB, Dijksterhuis JP, Ganji RS, Bryja V and Schulte G. (2011) WNT-5A stimulates the GDP/GTP exchange at pertussis toxin-sensitive heterotrimeric G proteins. Cell Signal 23: 550-4 [PMID:21070854]

88. Kilander MB, Petersen J, Andressen KW, Ganji RS, Levy FO, Schuster J, Dahl N, Bryja V and Schulte G. (2014) Disheveled regulates precoupling of heterotrimeric G proteins to Frizzled 6. FASEB J 28: 2293-305 [PMID:24500924]

89. Kim GH and Han JK. (2007) Essential role for beta-arrestin 2 in the regulation of Xenopus convergent extension movements. EMBO J 26: 2513-26 [PMID:17476309]

90. Kim M, Lee HC, Tsedensodnom O, Hartley R, Lim YS, Yu E, Merle P and Wands JR. (2008) Functional interaction between Wnt3 and Frizzled-7 leads to activation of the Wnt/beta-catenin signaling pathway in hepatocellular carcinoma cells. J Hepatol 48: 780-91 [PMID:18313787]

91. King TD, Zhang W, Suto MJ and Li Y. (2012) Frizzled7 as an emerging target for cancer therapy. Cell Signal 24: 846-51 [PMID:22182510]

92. Kirikoshi H, Koike J, Sagara N, Saitoh T, Tokuhara M, Tanaka K, Sekihara H, Hirai M and Katoh M. (2000) Molecular cloning and genomic structure of human frizzled-3 at chromosome 8p21. Biochem Biophys Res Commun 271: 8-14 [PMID:10777673]

93. Kirikoshi H, Sagara N, Koike J, Tanaka K, Sekihara H, Hirai M and Katoh M. (1999) Molecular cloning and characterization of human Frizzled-4 on chromosome 11q14-q21. Biochem Biophys Res Commun 264: 955-61 [PMID:10544037]

94. Kirikoshi H, Sekihara H and Katoh M. (2001) Up-regulation of Frizzled-7 (FZD7) in human gastric cancer. Int J Oncol 19: 111-5 [PMID:11408930]

95. Klein D, Demory A, Peyre F, Kroll J, Augustin HG, Helfrich W, Kzhyshkowska J, Schledzewski K, Arnold B and Goerdt S. (2008) Wnt2 acts as a cell type-specific, autocrine growth factor in rat hepatic sinusoidal endothelial cells cross-stimulating the VEGF pathway. Hepatology 47: 101831 [PMID:18302287]

96. Kolben T, Peröbner I, Fernsebner K, Lechner F, Geissler C, Ruiz-Heinrich L, Capovilla S, Jochum $\mathrm{M}$ and Neth P. (2012) Dissecting the impact of Frizzled receptors in Wnt/B-catenin signaling of human mesenchymal stem cells. Biol Chem 393: 1433-47 [PMID:23152409]

97. Kondo H, Hayashi H, Oshima K, Tahira T and Hayashi K. (2003) Frizzled 4 gene (FZD4) mutations in patients with familial exudative vitreoretinopathy with variable expressivity. $\mathrm{Br} \mathrm{J}$ Ophthalmol 87: 1291-5 [PMID:14507768]

98. Kondo H, Qin M, Tahira T, Uchio E and Hayashi K. (2007) Severe form of familial exudative vitreoretinopathy caused by homozygous R417Q mutation in frizzled-4 gene. Ophthalmic Genet 28: 220-3 [PMID:18161623]

99. Koval A and Katanaev VL. (2011) Wnt3a stimulation elicits G-protein-coupled receptor properties of mammalian Frizzled proteins. Biochem J 433: 435-40 [PMID:21128903]

100. Koval A, Purvanov V, Egger-Adam D and Katanaev VL. (2011) Yellow submarine of the Wnt/Frizzled signaling: submerging from the G protein harbor to the targets. Biochem Pharmacol 82: 1311-9 [PMID:21689640]

101. Kozielewicz P, Bowin CF, Turku A and Schulte G. (2020) A NanoBRET-Based Binding Assay for Smoothened Allows Real-time Analysis of Ligand Binding and Distinction of Two Binding Sites for BODIPY-cyclopamine. Mol Pharmacol 97: 23-34 [PMID:31707356]

102. Kozielewicz P, Turku A, Bowin CF, Petersen J, Valnohova J, Cañizal MCA, Ono Y, Inoue A, Hoffmann C and Schulte G. (2020) Structural insight into small molecule action on Frizzleds. Nat Commun 11: 414 [PMID:31964872]

103. Kumar S, Zigman M, Patel TR, Trageser B, Gross JC, Rahm K, Boutros M, Gradl D, Steinbeisser $\mathrm{H}$ and Holstein $\mathrm{T}$ et al.. (2014) Molecular dissection of Wnt3a-Frizzled8 interaction reveals essential and modulatory determinants of Wnt signaling activity. BMC Biol 12: 44 [PMID:24885675] 
104. Laeremans H, Hackeng TM, van Zandvoort MA, Thijssen VL, Janssen BJ, Ottenheijm HC, Smits JF and Blankesteijn WM. (2011) Blocking of frizzled signaling with a homologous peptide fragment of wnt3a/wnt5a reduces infarct expansion and prevents the development of heart failure after myocardial infarction. Circulation 124: 1626-35 [PMID:21931076]

105. Lapointe E, Boyer A, Rico C, Paquet M, Franco HL, Gossen J, DeMayo FJ, Richards JS and Boerboom D. (2012) FZD1 regulates cumulus expansion genes and is required for normal female fertility in mice. Biol Reprod 87: 104 [PMID:22954793]

106. Le Grand F, Jones AE, Seale V, Scimè A and Rudnicki MA. (2009) Wnt7a activates the planar cell polarity pathway to drive the symmetric expansion of satellite stem cells. Cell Stem Cell 4: 53547 [PMID:19497282]

107. Li B, Zhong L, Yang X, Andersson T, Huang M and Tang SJ. (2011) WNT5A signaling contributes to A 3 -induced neuroinflammation and neurotoxicity. PLoS ONE 6: e22920 [PMID:21857966]

108. Liu C, Wang Y, Smallwood PM and Nathans J. (2008) An essential role for Frizzled5 in neuronal survival in the parafascicular nucleus of the thalamus. J Neurosci 28: 5641-53 [PMID:18509025]

109. Liu T, Liu X, Wang Hy, Moon RT and Malbon CC. (1999) Activation of rat frizzled-1 promotes Wnt signaling and differentiation of mouse F9 teratocarcinoma cells via pathways that require Galpha(q) and Galpha(o) function. J Biol Chem 274: 33539-44 [PMID:10559239]

110. Lu D, Zhao Y, Tawatao R, Cottam HB, Sen M, Leoni LM, Kipps TJ, Corr M and Carson DA. (2004) Activation of the Wnt signaling pathway in chronic lymphocytic leukemia. Proc Natl Acad Sci USA 101: 3118-23 [PMID:14973184]

111. Lu J, Zhang S, Nakano H, Simmons DG, Wang S, Kong S, Wang Q, Shen L, Tu Z and Wang W et al.. (2013) A positive feedback loop involving Gcm1 and Fzd5 directs chorionic branching morphogenesis in the placenta. PLoS Biol 11: e1001536 [PMID:23610556]

112. Lu X, Peng Y, Wang C, Yang J, Bao X, Dong Q, Zhao W, Tan W and Dong X. (2017) Design, synthesis, and biological evaluation of optimized phthalazine derivatives as hedgehog signaling pathway inhibitors. Eur J Med Chem 138: 384-395 [PMID:28688278]

113. Luchetti G, Sircar R, Kong JH, Nachtergaele S, Sagner A, Byrne EF, Covey DF, Siebold C and Rohatgi R. (2016) Cholesterol activates the G-protein coupled receptor Smoothened to promote Hedgehog signaling. Elife 5 [PMID:27705744]

114. Luhmann UF, Neidhardt J, Kloeckener-Gruissem B, Schäfer NF, Glaus E, Feil S and Berger W. (2008) Vascular changes in the cerebellum of Norrin /Ndph knockout mice correlate with high expression of Norrin and Frizzled-4. Eur J Neurosci 27: 2619-28 [PMID:18547247]

115. Lum L and Beachy PA. (2004) The Hedgehog response network: sensors, switches, and routers. Science 304: 1755-9 [PMID:15205520]

116. Luo J, Chen J, Deng ZL, Luo X, Song WX, Sharff KA, Tang N, Haydon RC, Luu HH and He TC. (2007) Wnt signaling and human diseases: what are the therapeutic implications? Lab Invest 87: 97-103 [PMID:17211410]

117. Lyons JP, Mueller UW, Ji H, Everett C, Fang X, Hsieh JC, Barth AM and McCrea PD. (2004) Wnt4 activates the canonical beta-catenin-mediated Wnt pathway and binds Frizzled-6 CRD: functional implications of Wnt/beta-catenin activity in kidney epithelial cells. Exp Cell Res 298: 369-87 [PMID:15265686]

118. Lyuksyutova AI, Lu CC, Milanesio N, King LA, Guo N, Wang Y, Nathans J, Tessier-Lavigne M and Zou Y. (2003) Anterior-posterior guidance of commissural axons by Wnt-frizzled signaling. Science 302: 1984-8 [PMID:14671310]

119. Ma L and Wang HY. (2007) Mitogen-activated protein kinase p38 regulates the Wnt/cyclic GMP/Ca2 + non-canonical pathway. J Biol Chem 282: 28980-90 [PMID:17684012]

120. Ma L and Wang HY. (2006) Suppression of cyclic GMP-dependent protein kinase is essential to the Wnt/cGMP/Ca2+ pathway. J Biol Chem 281: 30990-1001 [PMID:16920709]

121. MacDonald BT and He X. (2012) Frizzled and LRP5/6 receptors for Wnt/ $\beta$-catenin signaling. Cold Spring Harb Perspect Biol 4 [PMID:23209147]

122. MacDonald BT, Tamai K and He X. (2009) Wnt/beta-catenin signaling: components, mechanisms, and diseases. Dev Cell 17: 9-26 [PMID:19619488]

123. MacDonald ML, Goldberg YP, Macfarlane J, Samuels ME, Trese MT and Shastry BS. (2005) Genetic variants of frizzled-4 gene in familial exudative vitreoretinopathy and advanced retinopathy of prematurity. Clin Genet 67: 363-6 [PMID:15733276]

124. Magdesian MH, Carvalho MM, Mendes FA, Saraiva LM, Juliano MA, Juliano L, Garcia-Abreu J and Ferreira ST. (2008) Amyloid-beta binds to the extracellular cysteine-rich domain of Frizzled and inhibits Wnt/beta-catenin signaling. J Biol Chem 283: 9359-68 [PMID:18234671]

125. Malaterre J, Ramsay RG and Mantamadiotis T. (2007) Wnt-Frizzled signalling and the many paths to neural development and adult brain homeostasis. Front Biosci 12: 492-506 [PMID:17127312]

126. Malik TH and Shivdasani RA. (2000) Structure and expression of a novel frizzled gene isolated from the developing mouse gut. Biochem J 349 Pt 3: 829-34 [PMID:10903145]

127. Manning DR, Shen F and Riobo NA. (2015) Evaluating the Activity of Smoothened Toward G Proteins Using [ $\left.{ }^{35} \mathrm{~S}\right]$ Guanosine 5'-(3-O-thio)triphosphate ([ $\left.\left.{ }^{35} \mathrm{~S}\right] \mathrm{GTP} \gamma \mathrm{S}\right)$. Methods Mol Biol 1322: 
35-44 [PMID:26179037]

128. Mao J, Ligon KL, Rakhlin EY, Thayer SP, Bronson RT, Rowitch D and McMahon AP. (2006) A novel somatic mouse model to survey tumorigenic potential applied to the Hedgehog pathway. Cancer Res 66: 10171-8 [PMID:17047082]

129. Masckauchán TN, Shawber CJ, Funahashi Y, Li CM and Kitajewski J. (2005) Wnt/beta-catenin signaling induces proliferation, survival and interleukin-8 in human endothelial cells. Angiogenesis 8: 43-51 [PMID:16132617]

130. Masdeu C, Faure H, Coulombe J, Schoenfelder A, Mann A, Brabet I, Pin JP, Traiffort E and Ruat M. (2006) Identification and characterization of Hedgehog modulator properties after functional coupling of Smoothened to G15. Biochem Biophys Res Commun 349: 471-9 [PMID:16945339]

131. Meloni AR, Fralish GB, Kelly P, Salahpour A, Chen JK, Wechsler-Reya RJ, Lefkowitz RJ and Caron MG. (2006) Smoothened signal transduction is promoted by G protein-coupled receptor kinase 2. Mol Cell Biol 26: 7550-60 [PMID:16908539]

132. Merle P, de la Monte S, Kim M, Herrmann M, Tanaka S, Von Dem Bussche A, Kew MC, Trepo C and Wands JR. (2004) Functional consequences of frizzled-7 receptor overexpression in human hepatocellular carcinoma. Gastroenterology 127: 1110-22 [PMID:15480989]

133. Miao Y, Ha A, de Lau W, Yuki K, Santos AJM, You C, Geurts MH, Puschhof J, PleguezuelosManzano C and Peng WC et al.. (2020) Next-Generation Surrogate Wnts Support Organoid Growth and Deconvolute Frizzled Pleiotropy In Vivo. Cell Stem Cell 27: 840-851.e6 [PMID:32818433]

134. Mikels AJ and Nusse R. (2006) Purified Wnt5a protein activates or inhibits beta-catenin-TCF signaling depending on receptor context. PLoS Biol 4: e115 [PMID:16602827]

135. Miyakoshi T, Takei M, Kajiya H, Egashira N, Takekoshi S, Teramoto A and Osamura RY. (2008) Expression of Wnt4 in human pituitary adenomas regulates activation of the beta-cateninindependent pathway. Endocr Pathol 19: 261-73 [PMID:19034702]

136. Montcouquiol M, Sans N, Huss D, Kach J, Dickman JD, Forge A, Rachel RA, Copeland NG, Jenkins NA and Bogani D et al.. (2006) Asymmetric localization of Vangl2 and Fz3 indicate novel mechanisms for planar cell polarity in mammals. J Neurosci 26: 5265-75 [PMID:16687519]

137. Moyes KW, Sip CG, Obenza W, Yang E, Horst C, Welikson RE, Hauschka SD, Folch A and Laflamme MA. (2013) Human embryonic stem cell-derived cardiomyocytes migrate in response to gradients of fibronectin and Wnt5a. Stem Cells Dev 22: 2315-25 [PMID:23517131]

138. Munchhof MJ, Li Q, Shavnya A, Borzillo GV, Boyden TL, Jones CS, LaGreca SD, Martinez-Alsina L, Patel N and Pelletier K et al.. (2012) Discovery of PF-04449913, a Potent and Orally Bioavailable Inhibitor of Smoothened. ACS Med Chem Lett 3: 106-11 [PMID:24900436]

139. Nagayama S, Fukukawa C, Katagiri T, Okamoto T, Aoyama T, Oyaizu N, Imamura M, Toguchida J and Nakamura Y. (2005) Therapeutic potential of antibodies against FZD 10, a cell-surface protein, for synovial sarcomas. Oncogene 24: 6201-12 [PMID:16007199]

140. Naz G, Pasternack SM, Perrin C, Mattheisen M, Refke M, Khan S, Gul A, Simons M, Ahmad W and Betz RC. (2012) FZD6 encoding the Wnt receptor frizzled 6 is mutated in autosomalrecessive nail dysplasia. Br J Dermatol 166: 1088-94 [PMID:22211385]

141. Neumann J, Schaale K, Farhat K, Endermann T, Ulmer AJ, Ehlers S and Reiling N. (2010) Frizzled1 is a marker of inflammatory macrophages, and its ligand Wnt3a is involved in reprogramming Mycobacterium tuberculosis-infected macrophages. FASEB J 24: 4599-612 [PMID:20667980]

142. Nile AH, de Sousa E Melo F, Mukund S, Piskol R, Hansen S, Zhou L, Zhang Y, Fu Y, Gogol EB and Kömüves LG et al.. (2018) A selective peptide inhibitor of Frizzled 7 receptors disrupts intestinal stem cells. Nat Chem Biol 14: 582-590 [PMID:29632413]

143. Nusse R. (2005) Wnt signaling in disease and in development. Cell Res 15: 28-32 [PMID:15686623]

144. Nusse R. (2003) Wnts and Hedgehogs: lipid-modified proteins and similarities in signaling mechanisms at the cell surface. Development 130: 5297-305 [PMID:14530294]

145. Ogden SK, Ascano Jr M, Stegman MA and Robbins DJ. (2004) Regulation of Hedgehog signaling: a complex story. Biochem Pharmacol 67: 805-14 [PMID:15104233]

146. Ogden SK, Fei DL, Schilling NS, Ahmed YF, Hwa J and Robbins DJ. (2008) G protein Galphai functions immediately downstream of Smoothened in Hedgehog signalling. Nature 456: $967-70$ [PMID:18987629]

147. Ohashi T, Oguro Y, Tanaka T, Shiokawa Z, Tanaka Y, Shibata S, Sato Y, Yamakawa H, Hattori H and Yamamoto Y et al.. (2012) Discovery of the investigational drug TAK-441, a pyrrolo[3,2c]pyridine derivative, as a highly potent and orally active hedgehog signaling inhibitor: modification of the core skeleton for improved solubility. Bioorg Med Chem 20: 5507-17 [PMID:22898254]

148. Pan W, Choi SC, Wang H, Qin Y, Volpicelli-Daley L, Swan L, Lucast L, Khoo C, Zhang X and Li L et al.. (2008) Wnt3a-mediated formation of phosphatidylinositol 4,5-bisphosphate regulates LRP6 phosphorylation. Science 321: 1350-3 [PMID:18772438]

149. Papadopoulou S and Edlund H. (2005) Attenuated Wnt signaling perturbs pancreatic growth but 
not pancreatic function. Diabetes 54: 2844-51 [PMID:16186384]

150. Petersen J, Wright SC, Rodríguez D, Matricon P, Lahav N, Vromen A, Friedler A, Strömqvist J, Wennmalm S and Carlsson J et al.. (2017) Agonist-induced dimer dissociation as a macromolecular step in G protein-coupled receptor signaling. Nat Commun 8: 226 [PMID:28790300]

151. Planutis K, Planutiene M, Moyer MP, Nguyen AV, Pérez CA and Holcombe RF. (2007) Regulation of norrin receptor frizzled-4 by Wnt2 in colon-derived cells. BMC Cell Biol 8: 12 [PMID:17386109]

152. Povelones M and Nusse R. (2005) The role of the cysteine-rich domain of Frizzled in WinglessArmadillo signaling. EMBO J 24: 3493-503 [PMID:16163385]

153. Qi X, Friedberg L, De Bose-Boyd R, Long T and Li X. (2020) Sterols in an intramolecular channel of Smoothened mediate Hedgehog signaling. Nat Chem Biol 16: 1368-1375 [PMID:32929279]

154. Qi X, Liu H, Thompson B, McDonald J, Zhang C and Li X. (2019) Cryo-EM structure of oxysterolbound human Smoothened coupled to a heterotrimeric $\mathrm{G}_{\mathrm{i}}$. Nature 571: 279-283 [PMID:31168089]

155. Qin M, Hayashi H, Oshima K, Tahira T, Hayashi K and Kondo H. (2005) Complexity of the genotype-phenotype correlation in familial exudative vitreoretinopathy with mutations in the LRP5 and/or FZD4 genes. Hum Mutat 26: 104-12 [PMID:15981244]

156. Raleigh DR, Sever N, Choksi PK, Sigg MA, Hines KM, Thompson BM, Elnatan D, Jaishankar P, Bisignano P and Garcia-Gonzalo FR et al.. (2018) Cilia-Associated Oxysterols Activate Smoothened. Mol Cell 72: 316-327.e5 [PMID:30340023]

157. Ramírez VT, Ramos-Fernández E, Henríquez JP, Lorenzo A and Inestrosa NC. (2016) Wnt-

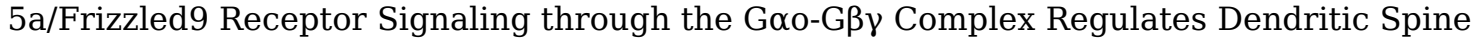
Formation. J Biol Chem 291: 19092-107 [PMID:27402827]

158. Ranchod TM, Ho LY, Drenser KA, Capone Jr A and Trese MT. (2011) Clinical presentation of familial exudative vitreoretinopathy. Ophthalmology 118: 2070-5 [PMID:21868098]

159. Ranheim EA, Kwan HC, Reya T, Wang YK, Weissman IL and Francke U. (2005) Frizzled 9 knockout mice have abnormal B-cell development. Blood 105: 2487-94 [PMID:15572594]

160. Rawal N, Castelo-Branco G, Sousa KM, Kele J, Kobayashi K, Okano H and Arenas E. (2006) Dynamic temporal and cell type-specific expression of Wnt signaling components in the developing midbrain. Exp Cell Res 312: 1626-36 [PMID:16510140]

161. Raza SI, Muhammad N, Khan S and Ahmad W. (2013) A novel missense mutation in the gene FZD6 underlies autosomal recessive nail dysplasia. Br J Dermatol 168: 422-5 [PMID:22861124]

162. Regard JB, Sato IT and Coughlin SR. (2008) Anatomical profiling of G protein-coupled receptor expression. Cell 135: 561-71 [PMID:18984166]

163. Riccio G, Bottone S, La Regina G, Badolati N, Passacantilli S, Rossi GB, Accardo A, Dentice M, Silvestri R and Novellino E et al.. (2018) A Negative Allosteric Modulator of WNT Receptor Frizzled 4 Switches into an Allosteric Agonist. Biochemistry 57: 839-851 [PMID:29293331]

164. Riobo NA and Manning DR. (2007) Pathways of signal transduction employed by vertebrate Hedgehogs. Biochem J 403: 369-379 [PMID:17419683]

165. Riobo NA, Saucy B, Dilizio C and Manning DR. (2006) Activation of heterotrimeric G proteins by Smoothened. Proc Natl Acad Sci USA 103: 12607-12 [PMID:16885213]

166. Robitaille J, MacDonald ML, Kaykas A, Sheldahl LC, Zeisler J, Dubé MP, Zhang LH, Singaraja RR, Guernsey DL, Zheng B, Siebert LF, Hoskin-Mott A, Trese MT, Pimstone SN, Shastry BS, Moon RT, Hayden MR, Goldberg YP and Samuels ME. (2002) Mutant frizzled-4 disrupts retinal angiogenesis in familial exudative vitreoretinopathy. Nat Genet 32: 326-330 [PMID:12172548]

167. Sagara N, Toda G, Hirai M, Terada M and Katoh M. (1998) Molecular cloning, differential expression, and chromosomal localization of human frizzled-1, frizzled-2, and frizzled-7. Biochem Biophys Res Commun 252: 117-22 [PMID:9813155]

168. Sahores M, Gibb A and Salinas PC. (2010) Frizzled-5, a receptor for the synaptic organizer Wnt7a, regulates activity-mediated synaptogenesis. Development 137: 2215-25 [PMID:20530549]

169. Saitoh T, Hirai M and Katoh M. (2001) Molecular cloning and characterization of human Frizzled-5 gene on chromosome 2q33.3-q34 region. Int J Oncol 19: 105-10 [PMID:11408929]

170. Saitoh T, Hirai M and Katoh M. (2001) Molecular cloning and characterization of human Frizzled-8 gene on chromosome 10p11.2. Int J Oncol 18: 991-6 [PMID:11295046]

171. Sala CF, Formenti E, Terstappen GC and Caricasole A. (2000) Identification, gene structure, and expression of human frizzled-3 (FZD3). Biochem Biophys Res Commun 273: 27-34 [PMID:10873558]

172. Salsano E, Paterra R, Figus M, Menghi F, Maderna E, Pollo B, Solero CL, Massimi L and Finocchiaro G. (2012) Expression profile of frizzled receptors in human medulloblastomas. $J$ Neurooncol 106: 271-80 [PMID:21850537]

173. Sammeta N, Yu TT, Bose SC and McClintock TS. (2007) Mouse olfactory sensory neurons express 10,000 genes. J Comp Neurol 502: 1138-56 [PMID:17444493]

174. Schihada H, Kowalski-Jahn M, Turku A and Schulte G. (2021) Deconvolution of WNT-induced 
Frizzled conformational dynamics with fluorescent biosensors. Biosens Bioelectron 177: 112948 [PMID:33486136]

175. Schulte G. (2010) International Union of Basic and Clinical Pharmacology. LXXX. The class Frizzled receptors. Pharmacol Rev 62: 632-67 [PMID:21079039]

176. Schulte G and Bryja V. (2007) The Frizzled family of unconventional G-protein-coupled receptors. Trends Pharmacol Sci 28: 518-25 [PMID:17884187]

177. Schulte G, Bryja V, Rawal N, Castelo-Branco G, Sousa KM and Arenas E. (2005) Purified Wnt-5a increases differentiation of midbrain dopaminergic cells and dishevelled phosphorylation. $J$ Neurochem 92: 1550-3 [PMID:15748172]

178. Schulte G and Wright SC. (2018) Frizzleds as GPCRs - More Conventional Than We Thought! Trends Pharmacol Sci 39: 828-842 [PMID:30049420]

179. Sen M, Lauterbach K, El-Gabalawy H, Firestein GS, Corr M and Carson DA. (2000) Expression and function of wingless and frizzled homologs in rheumatoid arthritis. Proc Natl Acad Sci USA 97: 2791-6 [PMID:10688908]

180. Shastry BS. (2009) Persistent hyperplastic primary vitreous: congenital malformation of the eye. Clin Experiment Ophthalmol 37: 884-90 [PMID:20092598]

181. Shen F, Cheng L, Douglas AE, Riobo NA and Manning DR. (2013) Smoothened is a fully competent activator of the heterotrimeric G protein G(i). Mol Pharmacol 83: 691-7 [PMID:23292797]

182. Shen G, Ke J, Wang Z, Cheng Z, Gu X, Wei Y, Melcher K, Xu HE and Xu W. (2015) Structural basis of the Norrin-Frizzled 4 interaction. Cell Res 25: 1078-81 [PMID:26227961]

183. Sinha S and Chen JK. (2006) Purmorphamine activates the Hedgehog pathway by targeting Smoothened. Nat Chem Biol 2: 29-30 [PMID:16408088]

184. Slusarski DC, Corces VG and Moon RT. (1997) Interaction of Wnt and a Frizzled homologue triggers G-protein-linked phosphatidylinositol signalling. Nature 390: 410-3 [PMID:9389482]

185. Slusher MM and Hutton WE. (1979) Familial exudative vitreoretinopathy. Am J Ophthalmol 87: 152-6 [PMID:434067]

186. Sonnet M, Claus R, Becker N, Zucknick M, Petersen J, Lipka DB, Oakes CC, Andrulis M, Lier A and Milsom MD et al.. (2014) Early aberrant DNA methylation events in a mouse model of acute myeloid leukemia. Genome Med 6: 34 [PMID:24944583]

187. Steinhart Z, Pavlovic Z, Chandrashekhar M, Hart T, Wang X, Zhang X, Robitaille M, Brown KR, Jaksani S and Overmeer R et al.. (2017) Genome-wide CRISPR screens reveal a Wnt-FZD5 signaling circuit as a druggable vulnerability of RNF43-mutant pancreatic tumors. Nat Med 23: 60-68 [PMID:27869803]

188. Stenson PD, Ball EV, Mort M, Phillips AD, Shiel JA, Thomas NS, Abeysinghe S, Krawczak M and Cooper DN. (2003) Human Gene Mutation Database (HGMD): 2003 update. Hum Mutat 21: 57781 [PMID:12754702]

189. Stone DM, Hynes M, Armanini M, Swanson TA, Gu Q, Johnson RL, Scott MP, Pennica D, Goddard A and Phillips $\mathrm{H}$ et al.. (1996) The tumour-suppressor gene patched encodes a candidate receptor for Sonic hedgehog. Nature 384: 129-34 [PMID:8906787]

190. Stuebner S, Faus-Kessler T, Fischer T, Wurst W and Prakash N. (2010) Fzd3 and Fzd6 deficiency results in a severe midbrain morphogenesis defect. Dev Dyn 239: 246-60 [PMID:19842188]

191. Su AI, Wiltshire T, Batalov S, Lapp H, Ching KA, Block D, Zhang J, Soden R, Hayakawa M and Kreiman $\mathrm{G}$ et al.. (2004) A gene atlas of the mouse and human protein-encoding transcriptomes. Proc Natl Acad Sci USA 101: 6062-7 [PMID:15075390]

192. Sugimura R, He XC, Venkatraman A, Arai F, Box A, Semerad C, Haug JS, Peng L, Zhong XB and Suda T et al.. (2012) Noncanonical Wnt signaling maintains hematopoietic stem cells in the niche. Cell 150: 351-65 [PMID:22817897]

193. Summerhurst K, Stark M, Sharpe J, Davidson D and Murphy P. (2008) 3D representation of Wnt and Frizzled gene expression patterns in the mouse embryo at embryonic day 11.5 (Ts19). Gene Expr Patterns 8: 331-48 [PMID:18364260]

194. Säfholm A, Tuomela J, Rosenkvist J, Dejmek J, Härkönen P and Andersson T. (2008) The Wnt-5aderived hexapeptide Foxy- 5 inhibits breast cancer metastasis in vivo by targeting cell motility. Clin Cancer Res 14: 6556-63 [PMID:18927296]

195. Taipale J, Chen JK, Cooper MK, Wang B, Mann RK, Milenkovic L, Scott MP and Beachy PA. (2000) Effects of oncogenic mutations in Smoothened and Patched can be reversed by cyclopamine. Nature 406: 1005-9 [PMID:10984056]

196. Takada R, Mii Y, Krayukhina E, Maruyama Y, Mio K, Sasaki Y, Shinkawa T, Pack CG, Sako Y and Sato C et al.. (2018) Assembly of protein complexes restricts diffusion of Wnt3a proteins. Commun Biol 1: 165 [PMID:30320232]

197. Tanaka S, Akiyoshi T, Mori M, Wands JR and Sugimachi K. (1998) A novel frizzled gene identified in human esophageal carcinoma mediates APC/beta-catenin signals. Proc Natl Acad Sci USA 95: 10164-9 [PMID:9707618]

198. Tauriello DV, Jordens I, Kirchner K, Slootstra JW, Kruitwagen T, Bouwman BA, Noutsou M, 
Rüdiger SG, Schwamborn K and Schambony A et al.. (2012) Wnt/B-catenin signaling requires interaction of the Dishevelled DEP domain and C terminus with a discontinuous motif in Frizzled. Proc Natl Acad Sci USA 109: E812-20 [PMID:22411803]

199. Teglund S and Toftgård R. (2010) Hedgehog beyond medulloblastoma and basal cell carcinoma. Biochim Biophys Acta 1805: 181-208 [PMID:20085802]

200. Terasaki H, Saitoh T, Shiokawa K and Katoh M. (2002) Frizzled-10, up-regulated in primary colorectal cancer, is a positive regulator of the WNT - beta-catenin - TCF signaling pathway. Int J Mol Med 9: 107-12 [PMID:11786918]

201. Tickenbrock L, Schwäble J, Wiedehage M, Steffen B, Sargin B, Choudhary C, Brandts C, Berdel WE, Müller-Tidow C and Serve H. (2005) Flt3 tandem duplication mutations cooperate with Wnt signaling in leukemic signal transduction. Blood 105: 3699-706 [PMID:15650056]

202. Toftgård R. (2000) Hedgehog signalling in cancer. Cell Mol Life Sci 57: 1720-1731 [PMID:11130178]

203. Tokuhara M, Hirai M, Atomi Y, Terada M and Katoh M. (1998) Molecular cloning of human Frizzled-6. Biochem Biophys Res Commun 243: 622-7 [PMID:9480858]

204. Traiffort E, Charytoniuk DA, Faure H and Ruat M. (1998) Regional distribution of Sonic Hedgehog, patched, and smoothened mRNA in the adult rat brain. J Neurochem 70: 1327-30 [PMID:9489757]

205. Tremblay MR, Lescarbeau A, Grogan MJ, Tan E, Lin G, Austad BC, Yu LC, Behnke ML, Nair SJ and Hagel $\mathrm{M}$ et al.. (2009) Discovery of a potent and orally active hedgehog pathway antagonist (IPI-926). J Med Chem 52: 4400-18 [PMID:19522463]

206. Tsutsumi N, Mukherjee S, Waghray D, Janda CY, Jude KM, Miao Y, Burg JS, Aduri NG, Kossiakoff AA and Gati C et al.. (2020) Structure of human Frizzled5 by fiducial-assisted cryoEM supports a heterodimeric mechanism of canonical Wnt signaling. Elife 9 [PMID:32762848]

207. Turner MW, Cruz R, Mattos J, Baughman N, Elwell J, Fothergill J, Nielsen A, Brookhouse J, Bartlett A and Malek P et al.. (2016) Cyclopamine bioactivity by extraction method from Veratrum californicum. Bioorg Med Chem 24: 3752-7 [PMID:27338657]

208. Tycko B, Li CM and Buttyan R. (2007) The Wnt/beta-catenin pathway in Wilms tumors and prostate cancers. Curr Mol Med 7: 479-89 [PMID:17691963]

209. Ueno K, Hirata H, Hinoda Y and Dahiya R. (2013) Frizzled homolog proteins, microRNAs and Wnt signaling in cancer. Int J Cancer 132: 1731-40 [PMID:22833265]

210. Ueno K, Hiura M, Suehiro Y, Hazama S, Hirata H, Oka M, Imai K, Dahiya R and Hinoda Y. (2008) Frizzled-7 as a potential therapeutic target in colorectal cancer. Neoplasia 10: 697-705 [PMID:18592008]

211. Uhlen M, Oksvold P, Fagerberg L, Lundberg E, Jonasson K, Forsberg M, Zwahlen M, Kampf C, Wester K and Hober S et al.. (2010) Towards a knowledge-based Human Protein Atlas. Nat Biotechnol 28: 1248-50 [PMID:21139605]

212. Uitterdijk A, Hermans KC, de Wijs-Meijler DP, Daskalopoulos EP, Reiss IK, Duncker DJ, Matthijs Blankesteijn W and Merkus D. (2016) UM206, a selective Frizzled antagonist, attenuates adverse remodeling after myocardial infarction in swine. Lab Invest 96: 168-76 [PMID:26658451]

213. van Amerongen R and Berns A. (2006) Knockout mouse models to study Wnt signal transduction. Trends Genet 22: 678-89 [PMID:17045694]

214. van Amerongen R and Nusse R. (2009) Towards an integrated view of Wnt signaling in development. Development 136: 3205-14 [PMID:19736321]

215. van Es JH, Jay P, Gregorieff A, van Gijn ME, Jonkheer S, Hatzis P, Thiele A, van den Born M, Begthel $\mathrm{H}$ and Brabletz T et al.. (2005) Wnt signalling induces maturation of Paneth cells in intestinal crypts. Nat Cell Biol 7: 381-6 [PMID:15778706]

216. van Gijn ME, Blankesteijn WM, Smits JF, Hierck B and Gittenberger-de Groot AC. (2001) Frizzled 2 is transiently expressed in neural crest-containing areas during development of the heart and great arteries in the mouse. Anat Embryol 203: 185-92 [PMID:11303904]

217. van Helden YG, Godschalk RW, Heil SG, Bunschoten A, Hessel S, Amengual J, Bonet ML, von Lintig J, van Schooten FJ and Keijer J. (2010) Downregulation of Fzd6 and Cthrc1 and upregulation of olfactory receptors and protocadherins by dietary beta-carotene in lungs of Bcmo1-/- mice. Carcinogenesis 31: 1329-37 [PMID:20472610]

218. Varecza Z, Kvell K, Talabér G, Miskei G, Csongei V, Bartis D, Anderson G, Jenkinson EJ and Pongracz JE. (2011) Multiple suppression pathways of canonical Wnt signalling control thymic epithelial senescence. Mech Ageing Dev 132: 249-56 [PMID:21549744]

219. von Maltzahn J, Bentzinger CF and Rudnicki MA. (2012) Wnt7a-Fzd7 signalling directly activates the Akt/mTOR anabolic growth pathway in skeletal muscle. Nat Cell Biol 14: 186-91 [PMID:22179044]

220. Wang C, Wu H, Evron T, Vardy E, Han GW, Huang XP, Hufeisen SJ, Mangano TJ, Urban DJ and Katritch V et al.. (2014) Structural basis for Smoothened receptor modulation and chemoresistance to anticancer drugs. Nat Commun 5: 4355 [PMID:25008467]

221. Wang C, Wu H, Katritch V, Han GW, Huang XP, Liu W, Siu FY, Roth BL, Cherezov V and Stevens 
RC. (2013) Structure of the human smoothened receptor bound to an antitumour agent. Nature 497: 338-43 [PMID:23636324]

222. Wang HQ, Xu ML, Ma J, Zhang Y and Xie CH. (2012) Frizzled-8 as a putative therapeutic target in human lung cancer. Biochem Biophys Res Commun 417: 62-6 [PMID:22138402]

223. Wang J, Mook Jr RA, Lu J, Gooden DM, Ribeiro A, Guo A, Barak LS, Lyerly HK and Chen W. (2012) Identification of a novel Smoothened antagonist that potently suppresses Hedgehog signaling. Bioorg Med Chem 20: 6751-7 [PMID:23063522]

224. Wang Y, Guo N and Nathans J. (2006) The role of Frizzled3 and Frizzled6 in neural tube closure and in the planar polarity of inner-ear sensory hair cells. J Neurosci 26: 2147-56 [PMID:16495441]

225. Wang Y, Huso D, Cahill H, Ryugo D and Nathans J. (2001) Progressive cerebellar, auditory, and esophageal dysfunction caused by targeted disruption of the frizzled-4 gene. J Neurosci $\mathbf{2 1}$ : 4761-71 [PMID:11425903]

226. Wang Y, Macke JP, Abella BS, Andreasson K, Worley P, Gilbert DJ, Copeland NG, Jenkins NA and Nathans J. (1996) A large family of putative transmembrane receptors homologous to the product of the Drosophila tissue polarity gene frizzled. J Biol Chem 271: 4468-76 [PMID:8626800]

227. Wang Y, Thekdi N, Smallwood PM, Macke JP and Nathans J. (2002) Frizzled-3 is required for the development of major fiber tracts in the rostral CNS. J Neurosci 22: 8563-73 [PMID:12351730]

228. Wang YK, Samos CH, Peoples R, Pérez-Jurado LA, Nusse R and Francke U. (1997) A novel human homologue of the Drosophila frizzled wnt receptor gene binds wingless protein and is in the Williams syndrome deletion at 7q11.23. Hum Mol Genet 6: 465-72 [PMID:9147651]

229. Wang YK, Spörle R, Paperna T, Schughart K and Francke U. (1999) Characterization and expression pattern of the frizzled gene Fzd9, the mouse homolog of FZD9 which is deleted in Williams-Beuren syndrome. Genomics 57: 235-48 [PMID:10198163]

230. Wang Z, Shu W, Lu MM and Morrisey EE. (2005) Wnt7b activates canonical signaling in epithelial and vascular smooth muscle cells through interactions with Fzd1, Fzd10, and LRP5. Mol Cell Biol 25: 5022-30 [PMID:15923619]

231. Wei J and Hemmings GP. (2004) Lack of a genetic association between the frizzled-3 gene and schizophrenia in a British population. Neurosci Lett 366: 336-8 [PMID:15288446]

232. Weierstall U, James D, Wang C, White TA, Wang D, Liu W, Spence JC, Bruce Doak R, Nelson G and Fromme P et al.. (2014) Lipidic cubic phase injector facilitates membrane protein serial femtosecond crystallography. Nat Commun 5: 3309 [PMID:24525480]

233. Wesslowski J, Kozielewicz P, Wang X, Cui H, Schihada H, Kranz D, Karuna M P, Levkin P, Gross JC and Boutros M et al.. (2020) eGFP-tagged Wnt-3a enables functional analysis of Wnt trafficking and signaling and kinetic assessment of Wnt binding to full-length Frizzled. J Biol Chem 295: 8759-8774 [PMID:32381507]

234. Willert K, Brown JD, Danenberg E, Duncan AW, Weissman IL, Reya T, Yates 3rd JR and Nusse R. (2003) Wnt proteins are lipid-modified and can act as stem cell growth factors. Nature 423: 44852 [PMID:12717451]

235. Willert K and Nusse R. (2012) Wnt proteins. Cold Spring Harb Perspect Biol 4: a007864 [PMID:22952392]

236. Willert KH. (2008) Isolation and application of bioactive Wnt proteins. Methods Mol Biol 468: 17-29 [PMID:19099243]

237. Winn RA, Marek L, Han SY, Rodriguez K, Rodriguez N, Hammond M, Van Scoyk M, Acosta H, Mirus J and Barry N et al.. (2005) Restoration of Wnt-7a expression reverses non-small cell lung cancer cellular transformation through frizzled-9-mediated growth inhibition and promotion of cell differentiation. J Biol Chem 280: 19625-34 [PMID:15705594]

238. Witze ES, Litman ES, Argast GM, Moon RT and Ahn NG. (2008) Wnt5a control of cell polarity and directional movement by polarized redistribution of adhesion receptors. Science 320: 365-9 [PMID:18420933]

239. Wright SC, Cañizal MCA, Benkel T, Simon K, Le Gouill C, Matricon P, Namkung Y, Lukasheva V, König GM and Laporte SA et al.. (2018) FZD 5 is a $\mathrm{G \alpha}_{\mathrm{q}}$-coupled receptor that exhibits the functional hallmarks of prototypical GPCRs. Sci Signal 11 [PMID:30514810]

240. Wright SC, Kozielewicz P, Kowalski-Jahn M, Petersen J, Bowin CF, Slodkowicz G, Marti-Solano M, Rodríguez D, Hot B and Okashah N et al.. (2019) A conserved molecular switch in Class F receptors regulates receptor activation and pathway selection. Nat Commun 10: 667 [PMID:30737406]

241. Wu QL, Zierold C and Ranheim EA. (2009) Dysregulation of Frizzled 6 is a critical component of B-cell leukemogenesis in a mouse model of chronic lymphocytic leukemia. Blood 113: 3031-9 [PMID:19179304]

242. Xie J, Murone M, Luoh SM, Ryan A, Gu Q, Zhang C, Bonifas JM, Lam CW, Hynes M and Goddard A et al.. (1998) Activating Smoothened mutations in sporadic basal-cell carcinoma. Nature 391 : 90-2 [PMID:9422511]

243. Xu L, Tan L, Goldring MB, Olsen BR and Li Y. (2001) Expression of frizzled genes in mouse 
costochondral chondrocytes. Matrix Biol 20: 147-51 [PMID:11334716]

244. Xu Q, Wang Y, Dabdoub A, Smallwood PM, Williams J, Woods C, Kelley MW, Jiang L, Tasman W and Zhang $\mathrm{K}$ et al.. (2004) Vascular development in the retina and inner ear: control by Norrin and Frizzled-4, a high-affinity ligand-receptor pair. Cell 116: 883-95 [PMID:15035989]

245. Yamada M, Iwabuchi T, Takahashi K, Kurahashi C, Ohata H, Honda K, Higuchi T and Yamada M. (2005) Identification and expression of frizzled-3 protein in rat frontal cortex after antidepressant and electroconvulsive treatment. J Pharmacol Sci 99: 239-46 [PMID:16258230]

246. Yanfeng WA, Tan C, Fagan RJ and Klein PS. (2006) Phosphorylation of frizzled-3. J Biol Chem 281: 11603-9 [PMID:16513654]

247. Yang J, Si T, Ling Y, Ruan Y, Han Y, Wang X, Zhang H, Kong Q, Li X and Liu C et al.. (2003) Association study of the human FZD3 locus with schizophrenia. Biol Psychiatry 54: 1298-301 [PMID:14643098]

248. Yang L, Wu X, Wang Y, Zhang K, Wu J, Yuan YC, Deng X, Chen L, Kim CC and Lau S et al.. (2011) FZD7 has a critical role in cell proliferation in triple negative breast cancer. Oncogene 30: 4437-46 [PMID:21532620]

249. Yang S, Wu Y, Xu TH, de Waal PW, He Y, Pu M, Chen Y, DeBruine ZJ, Zhang B and Zaidi SA et al.. (2018) Crystal structure of the Frizzled 4 receptor in a ligand-free state. Nature 560: 666670 [PMID:30135577]

250. Ye X, Wang Y, Cahill H, Yu M, Badea TC, Smallwood PM, Peachey NS and Nathans J. (2009) Norrin, frizzled-4, and Lrp5 signaling in endothelial cells controls a genetic program for retinal vascularization. Cell 139: 285-98 [PMID:19837032]

251. Ye X, Wang Y, Rattner A and Nathans J. (2011) Genetic mosaic analysis reveals a major role for frizzled 4 and frizzled 8 in controlling ureteric growth in the developing kidney. Development 138: 1161-72 [PMID:21343368]

252. Yoshida S, Arita R, Yoshida A, Tada H, Emori A, Noda Y, Nakao S, Fujisawa K and Ishibashi T. (2004) Novel mutation in FZD4 gene in a Japanese pedigree with familial exudative vitreoretinopathy. Am J Ophthalmol 138: 670-1 [PMID:15488808]

253. You J, Nguyen AV, Albers CG, Lin F and Holcombe RF. (2008) Wnt pathway-related gene expression in inflammatory bowel disease. Dig Dis Sci 53: 1013-9 [PMID:17939044]

254. Yu H, Smallwood PM, Wang Y, Vidaltamayo R, Reed R and Nathans J. (2010) Frizzled 1 and frizzled 2 genes function in palate, ventricular septum and neural tube closure: general implications for tissue fusion processes. Development 137: 3707-17 [PMID:20940229]

255. Yu H, Ye X, Guo N and Nathans J. (2012) Frizzled 2 and frizzled 7 function redundantly in convergent extension and closure of the ventricular septum and palate: evidence for a network of interacting genes. Development 139: 4383-94 [PMID:23095888]

256. Zerlin M, Julius MA and Kitajewski J. (2008) Wnt/Frizzled signaling in angiogenesis. Angiogenesis 11: 63-9 [PMID:18253847]

257. Zhang W, Lu W, Ananthan S, Suto MJ and Li Y. (2017) Discovery of novel frizzled-7 inhibitors by targeting the receptor's transmembrane domain. Oncotarget 8: 91459-91470 [PMID:29207657]

258. Zhang X, Zhao F, Wu Y, Yang J, Han GW, Zhao S, Ishchenko A, Ye L, Lin X and Ding K et al.. (2017) Crystal structure of a multi-domain human smoothened receptor in complex with a super stabilizing ligand. Nat Commun 8: 15383 [PMID:28513578]

259. Zhang XM, Ramalho-Santos M and McMahon AP. (2001) Smoothened mutants reveal redundant roles for Shh and Ihh signaling including regulation of L/R asymmetry by the mouse node. Cell 105: 781-92 [PMID:11440720]

260. Zhang Y, Yu X, Yuan Y, Ling Y, Ruan Y, Si T, Lu T, Wu S, Gong X and Zhu Z et al.. (2004) Positive association of the human frizzled 3 (FZD3) gene haplotype with schizophrenia in Chinese Han population. Am J Med Genet B Neuropsychiatr Genet 129B: 16-9 [PMID:15274031]

261. Zhao C, Avilés C, Abel RA, Almli CR, McQuillen P and Pleasure SJ. (2005) Hippocampal and visuospatial learning defects in mice with a deletion of frizzled 9, a gene in the Williams syndrome deletion interval. Development 132: 2917-27 [PMID:15930120]

262. Zhao C and Pleasure SJ. (2005) Frizzled9 protein is regionally expressed in the developing medial cortical wall and the cells derived from this region. Brain Res Dev Brain Res 157: 93-7 [PMID:15939089]

263. Zhao Y, Ren J, Hillier J, Lu W and Jones EY. (2020) Antiepileptic Drug Carbamazepine Binds to a Novel Pocket on the Wnt Receptor Frizzled-8. J Med Chem 63: 3252-3260 [PMID:32049522]

264. Zhao Z, Lee CC, Baldini A and Caskey CT. (1995) A human homologue of the Drosophila polarity gene frizzled has been identified and mapped to 17q21.1. Genomics 27: 370-3 [PMID:7558010] 